\title{
Optic disc coloboma with pit treated as glaucoma: diagnostic utility of ultrasound and swept source optical coherence tomography
}

\author{
Brijesh Takkar, Pradeep Venkatesh, Divya Agarwal, Atul Kumar
}

Dr Rajendra Prasad Centre for Ophthalmic Sciences, All India Institute of Medical Sciences, New Delhi, India

\section{Correspondence to} Dr Brijesh Takkar, britak.aiims@gmail.com

Accepted 16 August 2017

\section{DESCRIPTION}

A 6-year-old boy presented as a known case of developmental glaucoma and was using topical travoprost in the right eye (RE) since 1 year. Highest recorded intraocular pressure (IOP) was $24 \mathrm{~mm} \mathrm{Hg}$ in RE, whereas central corneal thickness was $540 \mu \mathrm{m}$. Visual acuity was $6 / 6$ in both eyes. On examination, the anterior segment of both eyes was unremarkable. IOP was $16 \mathrm{~mm} \mathrm{Hg}$ in RE and $20 \mathrm{~mm} \mathrm{Hg}$ in the left eye. Fundus examination of RE revealed a large and pale optic disc, with a nearly absent inferior neuroretinal rim. The origin of the inferior vascular bundle could not be deciphered, and there was a small atrophic patch inferior to the optic disc (figure 1). A suspicious cavity-like macular lesion was noted adjoining the nasal border of fovea. The fellow eye had a type 3 choroidal coloboma sparing the macula (Ida Mann classification system). Standard automated perimetry showed a

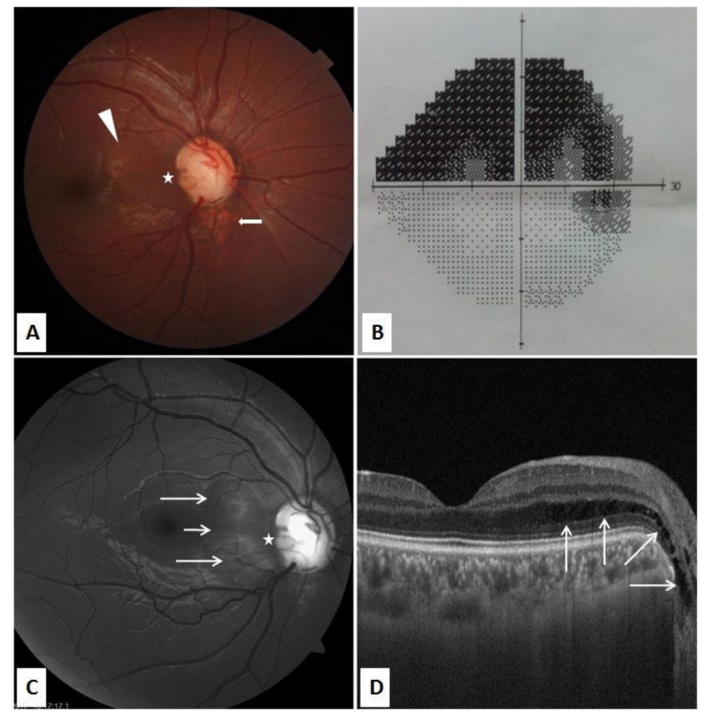

Figure 1 (A) Fundus photograph of the right eye showing the inferiorly excavated optic disc with doubtful optic disc pit temporally (star). An atrophic patch inferior to the optic disc (arrow) and a cavity-like macular lesion (arrowhead) are also seen. (B) Glaucoma hemifield test plot of a standard 30-degree automated perimetry depicts a large superior arcuate defect. (C) The macular lesions (arrows) and the optic disc coloboma with pit (star) are better appreciated in red-free imaging mode. (D) Optical coherence tomography image shows a line scan of the macular lesion. Schisis of the macular layers that extend within the optic nerve tissue can be visualised (arrows). The foveola is unaffected. large superior arcuate scotoma (figure 1). Swept source optical coherence tomography (SSOCT) of the suspicious lesion showed schisis of the retinal layers nasal to fovea, which could be traced until within the optic disc (figure 1).

Optic disc coloboma (ODC) with pit was suspected in RE. Ultrasound of RE revealed an inferiorly decentred excavation within the superficial optic disc tissue, whereas no such lesion was visualised in the fellow eye (figure 2A). SSOCT showed an excavated optic disc with pit confirming the diagnosis of $\mathrm{RE}$ (figure 2B). Herniation of the retinal tissue over the pit cavity, vitreous traction and communication of the pit cavity with macular schisis at the temporal border of the optic disc were also noted. Antiglaucoma medication was stopped, and frequent monitoring of IOP and macular status along with laser delimitation of the left eye coloboma was advised. The child is stable until a follow-up of 3 months.

Congenital anomalies of the optic disc can mimic glaucoma due to overlapping clinical features and similar visual field defects. Nearly one-third of patients with optic disc pit have visual field defects, the the most common being an arcuate scotoma. ${ }^{1}$ Imaging should be used in such doubtful cases for ascertaining correct diagnosis. SSOCT has the ability to provide high-resolution images at deeper tissue levels and is a good tool for imaging ODC with pit. ${ }^{2}$ A large SSOCT imaging series on

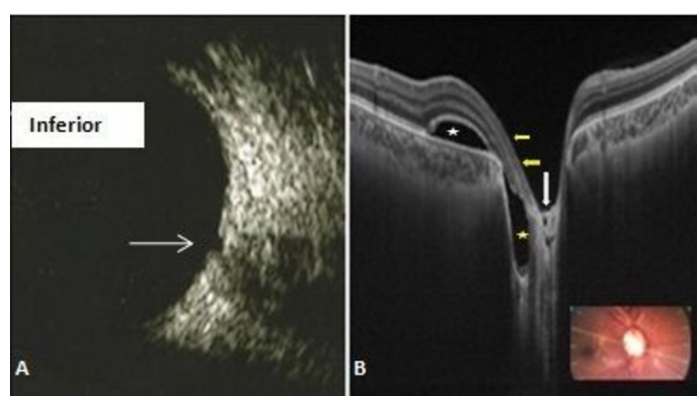

Figure 2 (A) Longitudinal B scan ultrasound image of the right eye (RE) shows a superficial excavation (arrow) in the inferior region of the optic disc. (B) Swept source optical coherence tomography (OCT) of the optic disc of the RE shows subretinal fluid cavity (white star) that communicates with the fluid cavity of the optic disc pit (yellow star). The retinal tissue is seen to herniate and cover the disc pit (yellow arrows) as it travels nasally. Dysplastic retinal/glial tissue can be seen in the deeply excavated optic disc coloboma region (white arrow). Inset fundus picture shows the orientation of the OCT scan. 
congenital optic disc anomalies has shown optic disc pits to vary in shape. They can be triangular or slit-like, whereas dehiscence of the lamina cribrosa is common. ${ }^{2}$ The pit may contain vitreous fibres and herniated retinal tissue and has been seen to be very close to the subarachnoid space in some cases. ${ }^{2}$ ODC has been imaged to be a deeply excavated area within the optic nerve with some common features with optic disc pit. ${ }^{2}$ Ultrasound has not been evaluated as a diagnostic tool in the perspective of an ODC and may be useful considering its larger availability. Optic disc

\section{Learning points}

- Congenital anomalies of the optic disc can be misdiagnosed as glaucoma.

- Imaging is useful in revealing the correct diagnosis in such cases.

- Ultrasound should be evaluated as an ancillary tool for assessment of optic disc coloboma. pit-related maculopathy may be managed with different surgical techniques. ${ }^{3}$ We advised follow-up as the foveola was uninvolved, and the child had good central vision.

Contributors $\mathrm{BT}, \mathrm{PV}$ and DA did the work-up. $\mathrm{BT}$ and DA performed the imaging. PV managed the patient. BT and PV wrote the manuscript. AK critically revised the manuscript. BT and PV hold overall responsibility for the manuscript content.

Competing interests None declared.

Patient consent Obtained from guardian.

Provenance and peer review Not commissioned; externally peer reviewed.

(c) BMJ Publishing Group Ltd (unless otherwise stated in the text of the article) 2017. All rights reserved. No commercial use is permitted unless otherwise expressly granted.

\section{REFERENCES}

1 Brown GC, Shields JA, Goldberg RE. Congenital pits of the optic nerve head. II. Clinical studies in humans. Ophthalmology 1980;87:51-65.

2 Ohno-Matsui K, Hirakata A, Inoue M, et al. Evaluation of congenital optic disc pits and optic disc colobomas by swept-source optical coherence tomography. Invest Ophthalmol Vis Sci 2013:54:7769-78.

3 Kumar A, Gogia V, Nagpal R, et al. Minimal gauge vitrectomy for optic disc pit maculopathy: Our results. Indian J Ophthalmol 2015;63:924-6.

Copyright 2017 BMJ Publishing Group. All rights reserved. For permission to reuse any of this content visit http://group.bmj.com/group/rights-licensing/permissions.

BMJ Case Report Fellows may re-use this article for personal use and teaching without any further permission.

Become a Fellow of BMJ Case Reports today and you can:

- Submit as many cases as you like

- Enjoy fast sympathetic peer review and rapid publication of accepted articles

- Access all the published articles

Re-use any of the published material for personal use and teaching without further permission

For information on Institutional Fellowships contact consortiasales@bmjgroup.com

Visit casereports.bmj.com for more articles like this and to become a Fellow 